\title{
Diferenças fonéticas entre o Tupí e o Guaraní
}

Aryon Dall'Igna Rodrigues

\section{A origem comum dos tupís e guaranís}

Alguns séculos antes da descoberta das Américas, havia na América do Sul, entre muitos outros, um tronco tribal e linguístico que se localizava nas regiões delimitadas pelos rios Paraná e Paraguai, aproximadamente onde está situada hoje a República do Paraguai ${ }^{1}$, cujos descendentes, mais tarde, na época da descoberta, depois de migrações diversas, constituíam os tupís e os guaranís encontrados pelos europeus.

Esse tronco, então homogêneo, com o correr do tempo, em obediência a fatores diversos, foi-se dispersando, por emigrações que se deram em várias épocas e em várias direções, quase todas ainda em época pré-histórica. A mais remota que se percebe, através dos resíduos linguísticos, alcançou o alto Amazonas, instalando-se ultimamente entre o Ucaiale e o Napo (afluentes do Morañón), sendo os descendentes dos migrantes representados atualmente pelos omáguas e cocamas e, talvez, também pelos miranhas, habitantes das margens do Japurá, afluente esquerdo do Alto Amazonas. Deram-se outras para noroeste, alcançando o atual território boliviano; para o sul, chegando até à região da atual província argentina da Santa Fé; para leste e nordeste, pelos atuais estados brasileiros do Paraná e de S. Paulo, alcançando o litoral atlântico estendendo-se por este até a altura do nordeste brasileiro; já em tempos históricos, do litoral nordeste dirigiu-se novo movimento migratório à região do Baixo Amazonas.

De todas essas migrações, a maior foi aquela que se dirigiu para o litoral atlântico e, daí, para o norte. Novo movimento migratório de oeste para leste

1. Paul Rivet, apud J. Bertolaso Stella. As línguas indígenas da América, S. Paulo, 1928; Rosário Farani Mansur Guérios, Novos rumos da tupinologia, Curitiba, 1935. 
se processou, segundo Paul Rivet, à obediência a motivos de ordem religiosa, muito mais tarde, nos princípios do século $\mathrm{XIX}^{2}$.

À língua desse tronco primitivo convencionou o prof. Rosário Farani Mansur Guérios, erudito linguista patrício, em seu precioso opúsculo "Novos Rumos da Tupinologia”, denominar Proto-Tupí-Guaraní ou Tupí-Guaraní comum: - "Por essa denominação, entende-se um estado linguístico homogêneo ou mais ou menos tal; é a primeira estratificação, a qual comporta particularidades linguísticas entrevistas antes da época histórica, i. é, antes dos fracionamentos dialetais"3.

Antes de se passar ao estudo do fracionamento do Proto-Tupí-Guaraní, quando dessas migrações, convém que fique assinalado que Joyce ${ }^{4}$, citado por A. Childe ${ }^{5}$, coloca a sede primitiva dos Tupí-Guaranís no centro do Brasil, na região das cabeceiras do Xingú e alto Araguaia, donde teriam descido até a embocadura do Prata e, daí, subido pela costa, até o Amazonas, enquanto que Karl von den Steinen divaga sobre se o seu centro de irradiação não se teria localizado naquela mesma região - nascentes do Xingú ${ }^{6}$.

\section{O fracionamento do Proto-Tupí-Guaraní}

Da partição do tronco primitivo Tupí-Guaraní, adveio o fracionamento linguístico, sendo derruída a primitiva unidade do Proto-Tupí-Guaraní e caracterizando-se, lenta, mas progressivamente, os dialetos.

Das várias migrações que se realizaram, observar-se-á aqui aquela que se deu no sentido de oeste para leste, em época pré-colombiana: os tupís ${ }^{7}$ deixaram o seu primitivo hábitat, dirigindo-se, em grande quantidade, para o oriente, atravessando os territórios dos atuais Estados do Paraná e S. Paulo, alcançando o litoral e distendendo-se por quase toda a costa, poucos séculos antes da descoberta, tendo essa emigração sido a mais considerável das que se processaram, aquela na qual maior número de indivíduos tomou parte. Pelo litoral, com o correr do tempo, foram os tupís dividindo-se em várias

2. J. Bertolaso Stella, As línguas indígenas da América, S. Paulo, 1928.

3. Rosário Farani Mansur Guérios, Novos rumos da tupinologia, Curitiba, 1935, p. 3.

4. Joyce, South American archeology.

5. A. Childe, Étude philologique sur les noms du "chien" de l'antiquité jusqu'à nos jours, in "Arquivos do Museu Nacional", vol. XXXIX, Rio, 1940, p. 345.

6. Karl von den Steinen, O Brasil Central, trad. de C. Baratz Canabrava, S. Paulo-RioRecife-P. Alegre, 1942, p. 374.

7. Designa-se aqui, por tupí, para facilidade de exposição, os ancestrais dos índios que mais tarde vieram a ser chamados assim. Antes da emigração não havia, claro está, diversidade entre tupís e guaranís, diversidade essa que mais tarde se caracterizou, mas que é de caráter unicamente linguístico. 
tribos, sendo que, no século XVI, foram encontradas pelos europeus as tribos: tupinambá, tupinaquim (tupiniquim, tupinanquim), tobajara (tabajara), tamoio, temiminõ (temininó), caeté, maracajá, etc. Por sua vez, os guaranís, que se mantiveram ao sul, também se dividiram em tribos várias, sendo a sua maioria conhecida pelo nome de carijó (kari'ó), estendendo-se desde o litoral até as regiões paraguaias, pelo sul do trópico de Capricórnio. O limite presumível entre os tupís e os guaranís devia coincidir com o limite entre os tupinambás ou os tamoios e os carijós, que, apesar de terem origem comum, eram inimigos, segundo diz Jean do Léry $(1557)^{8}$.

Tendo-se separado os tupís dos guaranís, o Proto-Tupí-Guaraní, que eles falavam, tomou rumos evolutivos diferentes junto a uns e a outros: distinguiram-se, então, dois dialetos do Proto-Tupí-Guaraní - o Proto-Tupi e o Proto-Guaraní. O Proto-Guaraní ou Guaraní comum ${ }^{9}$ é, pois, a língua que ficou sendo falada nas regiões paraguaias e pelas tribos que se espalharam daí para o oriente, pelo sul do trópico de Capricórnio, i. é, a língua que ficou sendo falada pelos guaranís. O Proto-Tupí ou Tupí comum é a língua que ficou sendo falada pelos tupís. Ambas as línguas apresentaram-se em estado mais ou menos unitário, homogêneo, somente em época pré-colombiana. Fracionaram-se também, à sua vez.

Quando os europeus desembarcaram na costa brasileira, as tribos tupí-guaranís, que eles encontraram, comportavam dois conjuntos de dialetos: um, ao norte da linha tropical, proveniente do Proto-Tupí, outro, ao sul, descendente do Proto-Guaraní. A esses dois conjuntos dialetais chama-se aqui ramo Tupí e ramo Guaraní, ou, simplesmente, Tupí e Guaraní, respectivamente.

Considerando-se, agora, os ramos Tupí e Guaraní, tem-se de reconhecer, ainda, mais uma divisão em cada um: o Tupí antigo e o Tupí moderno ${ }^{10}$, por um lado, e o Guaraní antigo e o Guaraní moderno, por outro lado. O Tupí moderno - conjunto de dialetos tupís hodiernos - tem o nome especial de Nheengatú e as tribos que o falam habitam a Amazônia; o Guaraní moderno - conjunto de dialetos guaranís hodiernos - é chamado Avanheém, sendo falado no sul do Brasil, Paraguai e adjacências.

8. Jean de Léry. História de uma viagem à terra do Brasil, trad. de Monteiro Lobato, Rio-S. Paulo, 1926, p.264.

9. Proto-tupí comum e proto-guaraní ou guaraní comum são também termos introduzidos na tupinologia pelo prof. Mansur Guérios (ob. cit., p. 17).

10. O tupí antigo vem desde o próprio proto-tupí até, aproximadamente, meados do séc. XVIII; o tupí moderno (Nheengatú) tem-se caracterizado nos sécs. XIX e XX. Mais ou menos, as mesmas épocas podem ser estabelecidas para o guaraní antigo e o guaraní moderno. 


\section{As principais diferenças fonéticas entre o Proto-Tupí e o Proto-Guaraní}

Já o Pe. José de Anchieta teve ocasião de registrar, sob o aspecto fonético, a diferença existente, no século XVI, entre os ramos Tupí e Guaraní. Diz o primeiro gramático do Tupí, na sua "Arte", que os índios do norte, "desde os Pitiguares do Paraíba até os Tamoios do Rio de Janeiro", pronunciavam "inteiros" os verbos terminados em consoante, como apâb, acêm, apên, aiûr, e mesmo, às vezes, apábi, etc., mormente quando compostos: apâbine, acêmine, apênine, aiùrine (futuro); enquanto que os índios do sul, "os Tupís de S. Vicente, que são além dos Tamoios do Rio de Janeiro", nunca pronunciavam a última consoante do verbo afirmativo, conservando ainda essa supressão nas formas compostas: apâ, ace(n), ape(n), aiú, apáne, acéne, apéne, aiúne, etc. ${ }^{11}$.

Essa é, na verdade, uma das duas principais diferenças distintivas dos dois ramos e que aqui serão estudadas; assim têm sido elas enunciadas: "a) em regra, o $s$ do $t$-. -gr. comum, inicial ou medial, conserva-se no Proto-Tupí, e torna-se $h$ no Proto-Guaraní; b) os vocábulos paroxítonos primitivos tornam-se neste, em geral, oxítonos pelo ensurdecimento da sílaba final átona; o que não se dá com o primeiro ramo que, em regra, são conservados" ${ }^{12}$. São deduções que se tiram, já à primeira vista, da contraposição de vocábulos tais como: Tupí yukü'ra : yukü', Guaraní, t. yagwára : yagwá gr., t. poránga : porã ' gr. ; t. só : hó gr., t. séra : héra gr., etc.

À época da descoberta (séc. XVI), esses dois fatos ainda se estavam definindo, indicando que não decorrera muito tempo desde que se iniciou a diferenciação. O que mais se havia caracterizado é o primeiro, a oposição de $h$ a $s$, mas que ainda estava em período de consumação, como se demonstrará adiante.

Determinadas assim as mais importantes diferenças fonéticas existentes entre o Proto-Tupí e o Proto-Guaraní, resta saber-se qual das duas línguas se alterou. Quando os tupís alcançaram o litoral atlântico, traziam consigo, por certo, o mesmo estado linguístico que haviam deixado no seu primitivo hábitat. Logo mais tarde, entretanto, foi-se divergindo o falar dos emigrados do dos que permaneceram no "Ursitz", mais os que se estenderam do interior até o litoral, pelo sul do trópico de Capricórnio (carijós) ${ }^{13}$. Surge aí o problema: alterou-se o falar dos tupís ou o dos guaranís, o dos que permaneceram em

11. P. Joseph de Anchieta, Arte de gramática da língua mais usada na costa do Brasil, ed. da Bibl. Nacional do Rio de Janeiro, Rio, 1933, f. 1, v.

12. R. Farani Mansur Guérios, ob. cit., p. 4. V. também Gal. Couto de Magalhães, O selvagem, $4^{\text {a }}$ ed., S. Paulo, 1940, p. 320; T. Sampaio, O tupí na geografia nacional, $2^{\mathrm{a}}$ ed., S. Paulo, 1914, p. 51.

13. Talvez essa grande migração dos tupís tenha sido provocada por rivalidades tribais, tendo sido estes obrigados a abandonar o seu hábitat, expelidas pela facção rival, guaraní 
seu hábitat primitivo ou o dos que emigraram? O simples fato da mudança de hábitat levaria a crer que foi o último que divergiu do primeiro, vindo a se caracterizar um dialeto da "Ursprache", a qual teria permanecido relativamente intacta no "Ursitz".

A observação dos fenômenos fonéticos nos dialetos registrados nos séculos XVI e XVII e, diacronicamente, através dos demais dialetos, até a atualidade, induzirá, entretanto, a se concluir pelo contrário (quanto àqueles dois fatos diferenciais, restritamente). O Proto-Tupí, quanto àqueles fatos, caracterizou-se mais conservador, mais arcaico do que o Proto-Guaraní.

Senão vejamos, examinando-se cada um à sua vez.

\section{As consoantes finais do Proto-Tupí-Guaraní}

Ao se assinalarem as diferenças fonéticas existentes entre os ramos Tupí e Guaraní, sempre tem sido frisada a contraposição de vocábulos paroxítonos tupís a vocábulos oxítonos guaranís, desprovidos estes da última sílaba átona apresentada por aqueles (V. p. 337). Os dialetos do Proto-Tupí registrados naqueles séculos XVI e XVII e, evidentemente, o próprio Proto-Tupí, entretanto, não apresentavam vocábulos verdadeiramente paroxítonos: eram vocábulos oxítonos, cuja sílaba final constituía-se de (consoante) + vogal + consoante, e que se tornavam, na frase, paroxítonos, pela afixação de índices (ou expoentes) vocálicos, monossilábicos e átonos à consoante final, como, p. ex.: potár : potári, poráng : poránga, piním : piníma, küsáb: küsába, úb: úba, ou, fazendo-se uso daqueles exemplos usados por Anchieta: páb: pábi: pába, úr : úri : úra, etc.

Examinando-se atentamente os vocabulários "brasílicos" de então, verifica-se que todos eles apresentam essas formas, quando não puramente terminadas em consoante $(-r,-m,-n,-k,-b,-n g)^{14}$, acrescidas daqueles índices vocálicos $(-a,-i)$ : Jean de Léry (1557): auc (= ók), "casa”, -répiac (= repiák),"ver”, -encg (= áng), "alma", a-aub (= aób), "roupa", yetic, "batata", se tam (= setám), "(sua) terra”, etc. ${ }^{15}$; Pe. Anchieta (1595); ôca, "casa”, acepiác (= asepiák), "vejo",

(aliás, gwariní, que significa "guerra”; gwarinihára"'guerreiro"), tendo ainda sido perseguidos, no seu êxodo, por estes, que chegaram a alcançar o litoral, vindo a ser conhecidos por carijós. 14. Seg. Anchieta, ob. cit., f. 8, v., e Figueira, “Arte”, p. 101, às vezes, permutava-se o -r pelo - $t$; segundo se vê em Anchieta, também o - $b$ pelo - $p$ (V. nota 15). Entre as consoantes finais citadas deve-se incluir também a semiconsoante $-y$.

15. As formas dadas por Léry, como é sabido, são muito estropiadas, já pela provável má pronúncia do "trugimão com oito anos de residência no país e muito senhor da língua da terra”, e mau ouvido do autor, já pelo descuido das impressões que se deu grande número de trocas de letras. É interessante observar que Léry raramente registra formas findadas em $-r$, apresentando sempre $-t$, do mesmo modo que apresenta $-p$ no lugar de $-b$. 
ánga, "alma", aiûr, "venho", acêm, "saio", aipotâr, "quero", túba e rúb, "pai", ména, "marido", etc.; Pe. Luís Figueira (1620): oca, "casa", ajúr, "venho", aixubán, "chupo", e ixubána, "chupá-lo", angaturáma, "virtude”, e xeangaturám, tenycem, "cousa cheia", etc. ${ }^{16}$.

Na obra do Pe. António Ruiz de Montoya $(1640)^{17}$, que reproduz o Guaraní falado no Baixo Paranapanema, no começo do séc. XVII, esses vocábulos, quando isolados, apresentam-se sem a consoante final e, por conseguinte, oxítonos; quando em composição, diante de vogais, deixam aparecer a consoante final, tanto que o Pe. Montoya, para distinguir esses vocábulos daqueles que terminam verdadeiramente em vogal tônica, convencionou escrever a consoante final separada da vogal tônica por um ponto, como, p. ex.: yû.r, "vir", tu.b, "pai", me(n).n, "marido", oque(n).n,"porta", cã.m "seios", potá.r, "querer", etc. Já no Guaraní de Montoya percebe-se a ausência frequente do índice - $a$, portando-se, pois, esses vocábulos semelhantemente aos que terminam verdadeiramente em vogal, os quais nunca recebiam tal índice.

Os mesmos vocábulos, ainda, nos dialetos guaranís modernos (Avanheém), não mais apresentam vestígios da consoante final ${ }^{18}$, sendo definitivamente oxítonos (ou monossílabos tônicos) terminados por vogal: $y u$, "vir", ru, "pai", oke(n), "porta", potá, "querer", se(n), "sair", yetî, "batata", etc. ${ }^{19}$. Ao mesmo tempo, os dialetos tupís modernos (Nheengatú) conservam ainda bem nítidas as formas paroxítonas, mais mesmo do que os dialetos tupís antigos ${ }^{20}$ : okéna,

16. Pe. Luís Figueira, Arte de gramática da língua brasílica, ed. de 1880, passim.

17. Pe. A. Ruiz de Montoya, Gramatica y diccionarios (Arte, vocabulario y tesoro) de la lengua tupi o guaraní, cd. de 1876 passim.

18. Nos que findavam em $-m,-n$ e $-n g$, restou a nasalação da vogal, ora final, que precedia essas consoantes; há palavras, entretanto, que já perderam essa nasalação, em alguns dialetos. Nos que findavam em - $g$ (proveniente de $-k$ ), segundo Moises Bertoni, a vogal que precedia essa consoante tornou-se "semigutural", como em üvá (g), "céu”, proveniente de übág (que provém, por sua vez, de übák) (Estructura, fundamentos gramaticales y clasificación de la lengua guaraní, In Rev. de la Soc. Científica delParaguay, t. V., nº 1, 1940 - pág. 32). Alguns vocábulos monossilábicos, apenas, conservaram a consoante final: $t$-er- $a$, ang- $a$, men- $a$, kam- $a$; não mais se lhes separa, porém, o antigo índice - $a$.

19. A. Ortiz Mayans, Breve diccionario guaraní-castellano castellano-guaraní, Bs. Aires, 1941. 20. No Nheengatú o índice - $a$ perdeu o seu valor semântico e, simultaneamente, o afixal, passando a constituir parte inseparável dos vocábulos que o recebiam; por outro lado, a analogia e, ainda mais, a tendência manifesta nas populações que falam o Nheengatú de facilitar a pronunciação, acrescentando após as consoantes finais uma vogal ( $-a,-e,-i$, -o), também têm contribuído muito para a extensão do número de vocábulos paroxítonos nos dialetos Nheengatú. 
"porta", óca, "casa", ména, "marido", putári, "querer", ce(n)mo, "sair", iúre, "vir", rúba, "pai", etc. ${ }^{21}$.

A única conclusão que se pode tirar desses fatos é, sem dúvida, que o Proto-Tupí-Guaraní possuía esses vocábulos terminados por consoante, i. é, * mén, *ók, "úb, " sém, " potár, " áng, "kám, " $y$-úr, etc. Daí, estabelecer-se-ão as seguintes leis fonéticas, na evolução do Proto-Tupí-Guaraní para o Proto-Guaraní e Avanheém, e para o Proto-Tupí e Nheengatú: $-1^{\circ}$ ) as consoantes finais de sílabas tônicas (de vocábulos oxítonos) Proto-Tupí-Guaranís conservaram-se no Proto-Tupí; $2^{\circ}$ ) as consoantes finais de sílabas tônicas (de vocábulos oxítonos) proto-tupís tornaram-se mediais no Nheengatú, pelo desenvolvimento ou acréscimo de uma vogal breve $\left.(-a,-e,-i,-o) ; 3^{\circ}\right)$ as consoantes finais de sílabas tônicas (de vocábulos oxítonos) Proto-Tupí-Guaranís desapareceram nos dialetos guaranís modernos (Avanheém); esta última lei, no século XVII (quando foi registrado o Guaraní de Montoya), estava em pleno dinamismo, motivo por que se depara na obra do Pe. Montoya o emprego mais ou menos arbitrário das formas com consoante final e sem consoante final. Esta fase evolutiva dos fonemas consoantes finais do Proto-Tupí-Guaraní, no século XVII, pode, mais ou menos exatamente, ser comparada com a que se tem caracterizado no português atual, aqui no Brasil (entre as populações das cidades), quando as mesmas pessoas pronunciam, ora fazer, ora fazế; ora andar, ora andá; ora fugir, ora fugí; ora vamos, ora vamo, etc. No português, entretanto, há um fator que procura reter o desenvolvimento do fenômeno, segundo a tendência inata dos indivíduos falantes: é o ensino da língua literária, que pretende uma fixidade máxima. Este fator, evidentemente, jamais poderia existir na língua indígena, e as exceções à lei fonética que se percebem nos atuais dialetos guaranís são devidas a outra ou outras leis interferentes, ou concorrentes.

\section{Os fonemas $\mathbf{S}: \mathbf{H}$}

Curiosamente, com relação aos fonemas Proto-Tupí $s: h$ Proto-Guaraní, processaram-se fenômenos inteiramente paralelos aos que já foram acima observados, relativamente à consoante final.

Bem evidencia isso a observação fonológica dos dialetos do Proto-Tupí e do Proto-Guaraní, antigos e modernos. Nos dialetos antigos do Proto-Tupí ressalta, ao primeiro exame, a inexistência completa do fonema aspirado $h$, abundando, por outro lado, o fonema fricativo dental surdo e; assim, registra Léry (1557): touroussou (= turusú), "grande", seta, "muitos", escendou (= esendú), "ouve!", -ressa, "olhos", essessit, "assa-o!", couarassi, "sol”, iassi, "lua”, resse,

21. Gal. Couto de Magalhães, Curso de língua tupí viva ou nheengatu, in O selvagem, do mesmo autor, $4^{\text {a }}$ ed., 1940, passim. 
"por", soo, "animal", mossaput, "três", etc.; Anchieta (1595): turuçû, "grande", cetâ, "muitos", teçá, "olhos", -recê, "por", moçapîr, "três", açô, "vou", açauçûb, "eu amo", çorib, "alegra-se", etc.; Figueira (1620): turuçú, "coisa grande", cetá, "muitos", recé, "por", moçapyt, "três", açó, "vou", açauçub, "eu amo", acendúb, "ouço", etc.

Em Montoya constata-se a mesma instabilidade já assinalada com referência às consoantes finais; aí têm-se: hetá, "muitos", ahendú, "ouço", teçá, "olho", aheci, "eu asso", quaraçi, "sol", yaci, "lua", rehé, "por", cóó, "animal", mbohapi, "três", ho, "ir", ahaihú, "eu amo", horib, "alegre", etc. Diz o Pe. Montoya, à pág. 146, v., do "Tesoro de la Lengua Guaraní": "La H. y la C (ante E) se suelen usar una por otra"; no correr do dicionário, apresentam-se vários vocábulos em que foi indicada a duplicidade fonética: "He(n), Salida, 1. Ce(n). Ahe(n), yo salgo, aunque no se usa en muchas partes, sino ace(n)". "Hi. p. b, Lo mismo que Çi, refregar". "Açocé, 1. Ahocé, 1. Coçé (sic), 1. Oçe (posposicion, lo mismo que supra), Sobrepujar, y abundancia”. "Ahóí, Cobrir. V. Açol’, etc.

No Avanheém, identicamente ao que se processou referentemente ao fenômeno já estudado, generalizou-se mais a pronúncia do fonema aspirado: kuarahü, "sol", hesüi, "assar", hetá, "muito", hendú, "ouvir", rehé, "por", hoó (:soó), "carne", mbohapü, "três", hó, "ir", haihú, "amar", horü, "alegre", aho-í, "cobrir", etc. Permaneceram, entretanto, com s: yasü, "lua”, tesá, "olho", se(n), "sair", hasü, "dor", sü, "mãe”, sã, "corda”, etc.

No Nheengatú, por outro lado, conserva-se completamente desconhecido o fonema aspirado do guaraní, não tendo, nesse setor, sido alterada a fonética do Proto-Tupí: turuçú, "grande", cetá, "muitos", cenõ, "ouvir", coaraçü²2, "sol", iaçü, "lua", recé, "por", çoó, "animal, carne", muçapüra, "três", çó, "ir", çaiçú, "amar", etc.

Inferir-se-á dessas observações que o fonema primitivo, o fonema proto-Tupí-Guaraní, é s, fricativa dental surda, enquanto que $h$ não foi conhecido no Proto-Tupí-Guaraní, tendo surgido nos dialetos do Proto-Guaraní (ou no próprio Proto-Guaraní, provavelmente). Isto posto, evidenciam-se as seguintes leis fonéticas: $1^{\circ}$ ) o fonema fricativo dental surdo $s$, do Proto-Tupí-Guaraní, manteve-se imutado no Proto-Tupí e em seus dialetos antigos e modernos; $2^{\circ}$ ) o mesmo fonema evoluiu para o fonema aspirado $h$, nos dialetos do Proto-Guaraní, sendo que, na época em que viveu o Pe. Montoya, i. é, no século

22. Substitui-se aqui por $h$ o $j h$ de Ortiz Mayans (ob. cit.), que representa um fonema semelhante ao $j$ espanhol, o qual, por influência espanhola, substitui na Argentina o $h$ dos demais dialetos guaranís (Bertoní, ob. cit., p.. 34). Substituem-se por $\ddot{u}$ as representações da vogal velar, não arredondada, empregadas por Ortiz Mayans e por Couto de Magalhães, em vista de não ser possível reproduzir aqui os sinais diacríticos empregados por esses autores afim de distiguí-la da vogal $i$ palatal. 
XVII, ainda se apresentava dinâmico o fenômeno.

Só investigações futuras poderão esclarecer qual o motivo por que alguns vocábulos dos dialetos modernos do Proto-Guaraní, como aqueles consignados acima, conservaram o fonema $s$. É muito interessante observar que esses mesmos vocábulos se apresentam com o fonema $h$ no Tembé e no Guajajara, falados no Pará e Maranhão, respectivamente, línguas estas nas quais houve semelhante evolução de $s$ para $h$. Assim, diz-se em Tembé ${ }^{23}$ (24): zahü', "lua”, kühé, "faca”, etc.; em Guajajara ${ }^{24}$ : çahü', "lua”, -kihé, "faca”, hi, "mãe”, rehá, “olho", etc., formas correspondentes a yasü’, küsé, sü, r-esá, dos vários dialetos tupís. Nessas duas línguas Tupí-Guaranís do norte do Brasil, que constituem verdadeiro X para a tupinologia ${ }^{25}$, este fenômeno não ficou aí, sobrepujando a generalização do fonema aspirado nos dialetos guaranís (todos os vocábulos acima citados mantiveram o $s$ nos dialetos guaranís), mas foi muito além: também o fonema fricativo palatal surdo $x$ evoluiu para $h$ : Tembé: taihó "sogra" (Tupí: taixó; Montoya: taichó), tuiháu, "chefe” (Tupí antigo: tubixáb; Tupí moderno: tuixáu; Montoya: tubichá.b; Avanheém: tuvichá), ihéu, ihéwe, "a mim" (Tupí antigo: ixébe; t. mod.: ixéu; Montoya: chébe; Avanheém: xéve), etc.

\section{Outras diferenças fonéticas}

Os fonemas $-k$ : $-g$. Os dialetos antigos do Proto-Tupí apresentavam o fonema final - $k$, explosiva gutural surda: Léry: auc (ók), “casa”; Anchieta: aicotúc, "eu furo", aimondôc, "corto", oçôc, "quebra-se", ocîc, "chegam", aipirôc, "tiro-lhe a pele", etc.; Figueira: oçóc, "ele pica”, apác, "acordo”, acyc, "chego", aguapyc, "estar assentado"; aimondóc, "corto”, etc. No Guaraní de Montoya jamais se apresenta essa consoante final, mas, sim, a correspondente sonora -g: og (:ók), cutúg (: -cotúc), mondóg (: mondôc), pág (:-pác), çog (: çóc), pirog (: pirôc), etc.

No Avanheém não mais se apresenta $\mathrm{o}-\mathrm{g}$, que foi elidido em obediência à $3^{\text {a }}$ lei enunciada de evolução das consoantes finais (V. p. 340), salvo em alguns vocábulos em que se conservou, já não como fonema final, é verdade, mas

23. Dr. Emil Heinrich Snethlage, Worteundtexte der Tembé-indianer, Aufgezeichnet von Cyriaco Baptista (Tembé), in Rev. del Instituto de Etnologia de la Universidad Nacional de Tucumán, t. II, entrega $2^{\text {a }}$, Tucumán, 1932. Foi aqui substituído por $\ddot{u}$ o $y$ com til de Ciriaco Batista.

24. S. Fróes de Abreu, Vocabulário Guajajara, in Na Terra das Palmeiras, do mesmo autor, Rio, 1931.

25. O Tembé e o Guajajara, pela sua localização geográfica, deveriam constituir elementos da corrente tupí que se estendeu da costa oriental para a Amazônia; entretanto, além do fato de apresentarem o $s$ evoluído para $h$, possuem muitas outras características fonéticas e léxicas do Guaraní, afora as características particularmente suas. Pretendemos, futuramente, focalizar especialmente esse problema. 
sim como medial, dada a fixação do sufixo - $a$ (V. p. 339, nota 18): oga "casa", $\operatorname{cog} a$ (Montoya $\operatorname{cog}$ ), "roça”. Excepcionalmente o Avanheém apresenta pák, "acordar".

O Nheengatú, por sua vez, conserva o fonema surdo, porém já não mais naquela posição final, mas sempre medial, em virtude da fixação do antigo índice - $a$ (V. p. 340 e nota 20): óca, "casa", munúca, "cortar", opáka, "acordou", reuapü’ ka!, "assente-se!", etc.

Em resumo: o fonema gutural surdo, final, $-k$, do Proto-Tupí-Guaraní assim se conservou no Proto-Tupí e dialetos antigos, tendo-se sonorizado no Proto-Guaraní e seus dialetos antigos; nos modernos dialetos guaranís (Avanheém), elidiu-se tal fonema, tendo-se conservado, entretanto, no Nheengatú, havendo-se-lhe aí, porém, sufixado um - $a$, passando, pois, a ser consoante medial.

A palatalização do fonema Proto-Tupí -s-. Quando, nos dialetos tupís, antepõe-se à fricativa dental surda $s$ - a vogal palatal não arredondada $i$-, ou a semiconsoante palatal $y$-, aquela fricativa é palatalizada: Anchieta: cì : ixì, "mãe" e "sua mãe", cibá : ixibá, "testa" e "sua testa", çáma : ixáma, "corda" e "sua corda", etc. ${ }^{26}$; Figueira: çumarã : ixumarã, "inimigo" e "seu inimigo", cy: ixy, "mãe" e "sua mãe", cyyra: ixyyra, "tia materna" e "sua tia", cybá : ixybá, "testa" e "sua testa", çáma: ixáma, "corda" e "sua corda", cóça : ixóca, "pilar" e "pilá-lo", cyba: ixyba, "alimpar" e "alimpá-lo", çó: ixó, "ir" e "seu ir" çuí: ixuí, "de" e "dele", çupé: ixupé, "a" e "a ele", etc. ${ }^{27}$

Este fenômeno fonético, que se caracterizou, sobretudo, no Tupí antigo, não se manifestou no Proto-Guaraní e dialetos antigos e modernos, a não ser em alguns casos isolados. Tem-se, em Montoya: suú : aysuú, "morder" e "eu o mordo", subã : aysubã, "chupar" e "eu o chupo", çoó : aiçoó, "convidar" e "eu o convido", etc. Casos excepcionais: Montoya: ychupé (por i-supé), ci : ychi, "mater" e "ejusmater"; Avanheém: ichupé, "a ele", ichuguí (= ixugwî), "dele".

A nasalização do fonema Proto-Guaraní y. Nos dialetos guaranís, antigos e modernos, quando à semiconsoante palatal $y$ se chega um fonema nasal, este transmite àquele a nasalidade, resultando daí a naso-palatal $\tilde{n}(n h)$. Este fenômeno é característico no Guaraní, pois realiza-se a todos os momentos, ainda mesmo quando o $y$ está separado do fonema nasal por uma sílaba não nasal; aliás, a nasalização é um fenômeno que se dá em grande escala, quase

26. Anchieta, ob. cit., f. 15, v.

27. Pe. Luís Figueira, ob. cit., págs. 74 e 75, onde abundam esses exemplos.

28. A nasalização é um capítulo da fonologia Tupí-Guaraní que merece um estudo especial, pois apresenta casos interessantíssimos, inclusive de fonética sintática. Relembremos aqui as palavras do grande glotólogo italiano, Alfredo Trobetti: "I fenomeni che io comprendo sotto il nome di nazalizzazione sono importantissimi e lo studio di essi, in 
exageradamente, dir-se-ia, no Guaraní ${ }^{28}$, e disso são testemunhas as obras de Montoya, onde não foi descurada a indicação das vogais nasaladas. Nos dialetos tupís quase nunca influem os fonemas nasais sobre o $y$.

Confrontações de Anchieta com Montoya: A. yandê: M. ñandé, "nós, inclus.", A. ayemboê : M. añemboé, "sou ensinado, aprendo", A. yanondê : M. ñanõndé, "antes", etc.; do Nheengatú com o Avanheém : nh. yamí: av. ñamí, "comprimir", nh. yandú : av. ñandú, "aranha", nh. yané: av. ñandé, "nós", nh. yandi, "azeite" : av. ñandü, "gordura, graxa", nh. yuséna, "derramar" : av. ñohe(n), "ação de derramar", nh. yapumí "mergulhar": av. mo-ñapümí, "ato de mergulhar", etc.

Os índices guaranís ye-, yo-, sempre que precedem uma sílaba nasal ou quando são precedidos por sílaba nasal (o índice mõ-), transformam-se em ñee ño-, respectivamente, i. é, nasalizam-se. O pronome $i$-, "seu, dele", vogal que, diante de outra vogal, passa a semiconsoante, também é nasalizado: $i-p o ́$, "sua mão" : i-aó, "sua roupa" : ñ-áng, "sua alma, sua sombra”; também ñ-akáng, "sua cabeça", apesar de não preceder imediatamente a sílaba nasal.

\section{Diferenças entre o Avanheém e o Nheengatú}

Foram já abordados os fatos que constituem as principais diferenças fonéticas entre o Tupí e o Guaraní, e que se podem considerar como já caracterizadas em época pré-colombiana, no Proto-Tupí e no Proto-Guaraní. Além desses fatos, outros há que se realizaram bem mais recentemente, evidenciando as diferentes tendências evolutivas dos ramos Tupí e Guaraní. Estes últimos são, pois, desconhecidos dos dialetos antigos, constituindo-se, também, caracteres distintivos do Nheengatú e Avanheém e do Tupí antigo e Guaraní antigo, respectivamente. Passar-se-á aqui a assinalá-los sucintamente.

$m b: m, n d: n$. Os fonemas naso-labial $m b$ e naso-dental $n d$, conhecidos em todos os dialetos antigos, do Proto-Tupí e do Proto-Guaraní não se alteraram no Avanheém; no Nheengatú, porém, evoluíram para $m$ e $n$, respectivamente, tanto quando iniciais como quando mediais. Sempre houve nos ramos Tupí e Guaraní a passagem de $m b-m$ e de $n d-n^{29}$, por dissimilação ou, simplesmente, quando os fonemas $m b$ e $n d$ precediam uma sílaba nasal (p. ex.,

massima parte novíssimo, rivela uma quantità di fatti sorpreendenti e fecondi di conseguenze di grande valore”. Elementi di glottologia, Bolonha, 1923, pág. 511. V. também "La nasalizzazione nel Tupi”, ibidem, pág. 543; Bertoni, ob. cit., pg. 32: “Antes del Descobrimiento, el processo de nasalización ya había llegado a su máximum en el Sud. Con todo, siguió aumentando y llega ahora a su más alto grado en el Paraguay y Corrientes, lo que por cierto no favorece a la eufonia, y parece que va a continuar".

29. " $m b-m$ " = " $m b$ passa para $m$ ", " $m b$ origina $m$ ". 
no Avanheém: nendivé por nde-ndivé, "contigo", ñnémba'é por ñandémba'é, "nosso", na-se(n)-i por nda-se(n)-i, "não saio", etc.). No Tupí antigo, contudo, já se percebe $m$-por $m b$-, inicial.

Algumas confrontações do Avanheém ${ }^{30}$ com o Nheengatú ${ }^{31}$ : av. mbohapü, : nh. musapü'rü, "três", cv. mbegué (= mbegwê) : nh. mewé, "lento", cv. mberú nh. merú, "mosca", cv. hembirecó : nh. semirecú, "esposa (dele)", av. cambü', "leite" nh. camü', "mama, peito", av. tanimbú : nh. tanimúca, "cinza", etc.; av. nde: nh. ne, "tu, teu”, av. pindá : nh. piná, "anzol”, av. mondó : nh. munú, "mandar, enviar", av. mundé: nh. munéu, "vestir", av. hendüvá: nh. senüwá, "barba", etc.

v : w. Todos os dialetos antigos do Proto-Tupí e do Proto-Guaraní possuem a explosiva bilabial sonora $b$, que, por isso mesmo, pode ser considerada como pertencente ao sistema fonético do Proto-Tupí e ao do Proto-Guaraní e, ainda, ao do Proto-Tupí-Guaraní. Atualmente, entretanto, já é inteiramente desconhecido esse fonema no Nheengatú e no Avanheém, onde evoluiu para $w(u)$ e

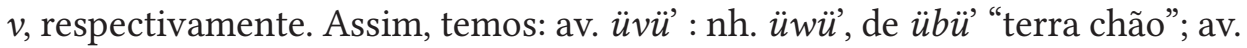
üvaté : nh. üwaté, de übaté, "alto"; av. küvü' : nh. küwéra, de kübürr, "irmão"; av. áva: nh. áwa, de áb(a), "cabelo"; av. vevé: nh. wewé, de bebé, "voar”; av. vavá: nh. wawáca, de *babák "oscilar, redemoinhar", etc.

gw : w. Os dialetos antigos do Proto-Tupí e do Proto-Guaraní apresentavam o fonema gúturo-labial sonoro $g w$ (escrito $g u$ ), que se pode ter como existente já no Proto-Tupí-Guaraní. Atualmente apresenta-se esse fonema conservado no Avanheém, ao passo que no Nheengatú tem-se a semiconsoante labial w: av. gwürá: nh. wirá, "pássaro", av. gwaimí: nh. waimí, "velha", av. gwasú : nh. wasú, "grande", av. gwatá : nh. watá, "andar", av. yagwá : nh. yawéra, "cão", av. mbegwé: nh. mewé, "devagar", etc.

o : u. No Nheengatú a vogal o dos demais dialetos tupís e guaranís está representada por $u$. Deve-se notar que o o dos dialetos tupís e guaranís é sempre fechado ${ }^{32}$ (o acento que se tem usado, pois, só indica a sílaba tônica). A evolução $o-u$ dá-se tanto quando a vogal é puramente oral, como quando é nasal: av., g. ant. hó, t. ant. só : nh. sú, "ir", t. ant., g. ant., av. soó : nh. suú, "carne", t. ant., g. ant., av. mondó : nh, munú, "mandar, enviar", t. ant., g. ant. manõ', av. manó : nh. manú, manú (n), "morrer” g. ant., t. ant., av. pó : nh. pú,

30. V. nota 23 à pág. 342 .

31. Pe. Constantino Tastevin, Vocabulário tupí-português, in Rev. do Museu Paulista, t. XIII, S. Paulo, 1923. Emprega-se aqui ü em lugar da representação usada pelo Pe. Tasteviri para a vogal velar, não arrdondada; indicam-se, também, as sílabas tônicas, que não vêm assinaladas nesse vocabulário.

32. V. também Plínio Ayrosa, Dos índices de relação determinativa de posse no tupí-guaraní, 5. Paulo, 1939, p. 21, nota. 
"mão", t ant., g. ant. tobá, av. tová : nh. tuá (por *tuwá), "rosto", etc.

Este fenômeno é de realização recentíssima, pois que ainda não se havia caracterizado na metade do século XIX, quando o Gal. Couto de Magalhães anotou seu material linguístico.

Além de todos esses fatos fonéticos relatados, há mais outras particularidades, não generalizadas ainda, leis fonéticas dinâmicas, cuja realização completa não se pode determinar. Vários dialetos Nheengatú, por exemplo, demonstram uma tendência à desnasalização das vogais finais tônicas:

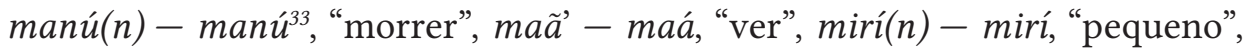
me’é(n) - me’é, "dar", cunhã - cunhá, "mulher", curumí(n) - curumí, "menino", etc. Em alguns dialetos guaranís modernos percebe-se uma tendência à deslocação da nasalidade, da última sílaba para a penúltima: porã - põrá, "bonito", hacã - hãcá, "galho", ha'ã - hã'á, "experimentar", hetã - he(n)tá, "terra (land)", pohã - põhá, "remédio", kirirí(n) - kiri(n)rí, "silêncio", hetú(n) - he(n)tú, "odor", heé(n) - he(n) é, "sim", etc. Também em dialetos guaranís modernos, percebe-se o ü substituindo o u primitivo: ürüvú por urubú, (ü)rügwasú por urugwasú, "galinha"; segundo Moisés Bertoni, é nos dialetos correntino e "asunceño" que mais se tem caracterizado este fenômeno ${ }^{34}$. Ainda no Avanheém percebe-se a queda do - $v$-intervocálico: kova - kóa, "este", hendivé - hendié "com ele", ñuvá - ñua "ação de abraçar", túva - túa, "pai”, mbovü’pa-mboü’pa, "quantos?", etc. Percebe-se, ainda, a evolução da semiconsoante palatal $y$ para o fonema denti-palatal $d j$, que se pode observar facilmente nos "Apontamentos para a Gramática Avá-ñeé", de Tenório d'Albuquerque: yuká - djuká, "matar", yuré - djurú, "boca”, yetü - djetü', "batata", yasü' - djasü, "lua", yogwá - djogwá, "comprar", yagwá - djagwá, "cão", yapó - diapó, "fazer", tayasá - tadjasú, "porco", etc.

Diversos fatos ainda poderiam ser abordados, fatos estes que vão contribuindo mais e mais para a diferenciação dos ramos Tupí e Guaraní, muitos decorrentes das influências portuguesa e espanhola, atuando esta sobre o Guaraní e aquela sobre o Tupí. São, entretanto, fatos que caracterizam áreas bem mais restritas, regionalismos que não podem ser aqui esmiuçados e que cabem mais aos estudos particulares de cada ramo.

Outras diferenças há entre os ramos Tupí e Guaraní, além das diferenças fonéticas que aqui foram estudadas. Na lexicologia, na morfologia e na sintaxe, patenteia-se também essa diferença. Aliás, é assunto que muito tem sido

33. V. observações sobre a grafia, à pág. 36.

34. M. Bertoni, ob. cit., p. 33. 
debatido; grande número de tupinólogos, ou guaraniólogos, insistem valentemente em protestar contra os maus conhecedores de linguística americana, que se referem a línguas inteiramente distintas. "Observa o general Couto de Magalhães" - diz Teodoro Sampaio - "que a diferença entre elas é a mesma que se nota entre paulistas e mineiros falando o português. Parece-nos, entretanto, que a diferença é um pouco mais acentuada como já fizera sentir o mesmo autor citado, no seu Estudo Antropológico, publicado na Revista do Instituto Histórico, onde, tratando do Tupí e do Guaraní, compara-os, no grau de semelhança ao português e ao castelhano"35.

Já o Dr. Moisés Bertoni, emérito guaraniólogo paraguaio, assim se exprime: "En realidad, los dialectos del guaraní ${ }^{36}$ poco difieren entre ellos..." "Mucho menos tienen rango de idiomas, o lenguas. Como se llegó a decir, La unidad del guaraní - desde las Antillas hasta las embocaduras del Plata - es un hecho que no puede ponerse en duda. El dualismo entre el achacado "tupí" (que es el ñeêngatú, o sea "lengua buena"), y el guaraní del Sud (avá'ñeé o karíñeé), ese supuesto dualismo, no existió, y sólo tuvo apariencias de existir, debido a la imperfección de los estudios. En realidad, eses dos grandes dialectos, o grupos dialectales, poco difieren, y además, se tienen todos los grados

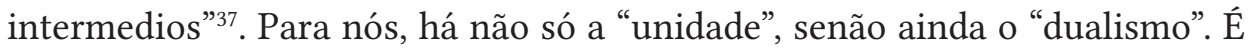
preciso que se considere o assunto por seus diversos aspectos. Sob o ponto de vista glotológico, não resta a mínima dúvida quanto à unidade: os ramos Tupí e Guaraní são muito estreitamente ligados entre si. Se, entretanto, encararmos estes dois ramos pelo lado prático, somos levados a reconhecer que, quem falasse o Tupí antigo, conseguia, mais ou menos, entender o Guaraní antigo, com dificuldade quase idêntica à que se oferece ao indivíduo de fala portuguesa para entender o espanhol. Mas quem fala o Nheengatú, podemos afiançar, não poderá compreender do Avanheém senão palavras soltas, podendo-se aqui comparar o grau de dificuldade, mais ou menos aproximadamente, com o que se depara ao português que ouve falar o francês. Explica-se, pois, que haja simultaneamente uma "unidade" e uma "dualidade", do mesmo modo que há, com relação às línguas românicas, uma "multiplicidade" e uma "unidade": unidade de origem, multiplicidade de variantes evolutivas; unidade glotológica, multiplicidade prática.

Seguimos aqui, por isso mesmo, os ensinamentos do prof. R. F. Mansur Guérios, admitindo o fracionamento da língua em estado unitário, homogêneo, ainda em época pré-colombiana, nas duas línguas também pré-históricas

35. T. Sampaio, O tupí na geografia nacional, $2^{\text {a }}$ ed., São Paulo. 1914. págs. 50-51. 36. O Dr. Bertoni dá a guaraní a mesma acepção que aqui damos a tupí-guaraní.

37. Bertoni, ob. cit., pág. 24. 
- o Proto-Tupí e o Proto-Guaraní (insistimos em frisar que ora cogitamos somente destes dois ramos, mas que, além destes, outros há, ainda). É esta, aliás, a única conclusão a que nos conduzem os fatos linguísticos.

Moisés Bertoni, neste ponto, confunde o assunto, pois que considera o Avanheém como oriundo do Nheengatú, crê num "paso de los dialectos del Norte y Noreste, o ñeêngatú, a los dialectos del Sud, o avá'ñeê", numa "evolución ñeêngatú - avá'ñeê", acrescentando que "la conquista guaraní y extensión de la raza, procedió en la dirección exactamente contraria a la que Martius indicó, e impuso a la ciencia durante un siglo"38.

Por outro lado, entretanto, Bertoni admite também um pre-guaraní, que corresponderia ao Proto-Tupí-Guaraní de Mansur Guérios, mas põe a origem do Guaraní diretamente fora da América, na Oceania e Ásia insular ("pues es sin duda de aquellas tierras del Pacífico que en máxima parte desaparecieron, de la Arquinesia, grupo de grandes islas, cercanas de Insulindia o Malesia, Filipinas y Japon- que los antiguos Karaívé vinieron a México y a la América Central, para de allí empezar, la milenaria conquista y sucesiva ocupación del inmenso Dominio Guaraní”) $)^{39}$, crendo ter descoberto uma conexão nipo-guaraní, declarando que "el japonés... en los caracteres fundamentales y su estructura orgánica presenta analogías considerables (con el guaraní)... En cambio, las diferencias son pocas, y se puede decir, que no hay ninguna fundamental entre las formas antiguas de ambas lenguas" ${ }^{\prime 4}$.

Pode ser assim resumida a teoria da evolução do Guaraní, segundo Bertoni:

preguaraní- karaivé - Nheengatú-Avanheém,

isto é, seguindo estritamente à ordem da migração, segundo sua teoria de Norte a Sul. Diz ele: "el karaívé, de las Antillas y Tierrafirme - el dialecto guaraní más antiguo que conocemos..."

Neste trabalho, como se depreende facilmente, seguimos uma teoria que assim pode ser resumida:

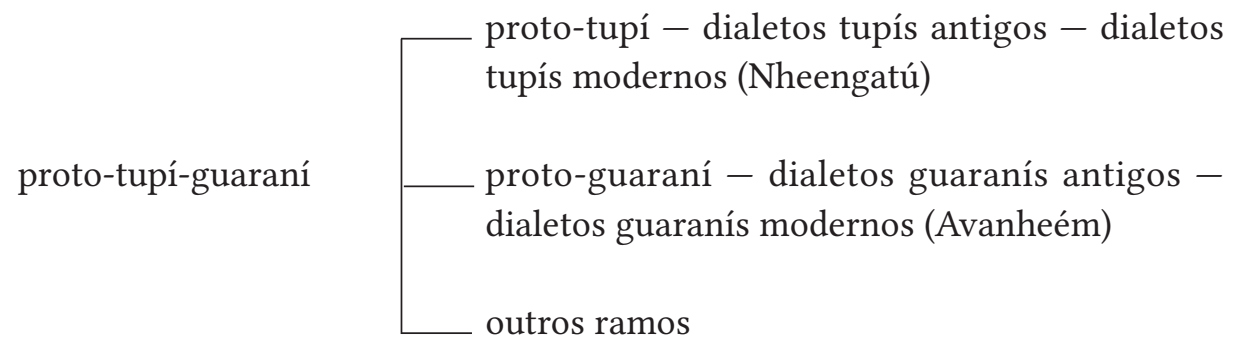

38. Ob. cit., pág. 29.

39. Ob. cit.,pág. 24 .

40. Ob. cit., pág. 25. Já é transcrição da obra do mesmo autor - Viaje de estudios al Brasil, Puerto Bertoni, 1923, págs. 70-71. 
Esta divisão é fundamentada na de Mansur Guérios, apresentada nos "Novos Rumos da Tupinologia” (§ IV, Classificação).

\section{Observações finais}

Os fatos comuns aos dialetos dum ramo, logicamente são admitidos como pertencentes já à língua mãe comum desses dialetos, à língua do "proto" respectiva; igualmente, os fatos comuns aos dois ramos estudados hão de se atribuir, também, ao Proto-Tupí-Guaraní. Assim, pois, se é observado que "peixe" é pirá, em todos os dialetos tupís, quer antigos, quer modernos, postular-se-á o vocábulo * pirá = "peixe", para o Proto-Tupí. Estendendo-se a investigação, descobre-se que em todos os dialetos guaranís, antigos e modernos, "peixe" é, também, pirá: admitir-se-á, para o Proto-Guaraní, a forma pirá = "peixe". Ampliando-se, ainda, o campo das observações, constata-se que outras línguas Tupí-Guaranís (Apiacá, Maué, Tembé, Guajajara, etc.) apresentam também a forma pirá = "peixe". Diante desse fato, inferir-se-á que o Proto-Tupí-Guaraní possuía, indubitavelmente, o vocábulo pirá = "peixe".

Assim foi que se procedeu aqui, ao se deduzirem algumas leis de evolução fonética do Proto-Tupí-Guaraní para os dialetos tupís e guaranís.

包

\section{Observações a respeito da grafia}

Tencionava-se uniformizar a grafia de todos os vocábulos Tupí-Guaranís citados neste estudo, adotando-se os caracteres gráficos mundialmente utilizados pelos linguistas. Dada, porém, a impossibilidade de serem reproduzidos pelo estabelecimento gráfico os sinais diacríticos de que se lançaria mão, preferiu-se conservar as grafias originais dos vários autores que foram alteradas apenas onde apresentavam sinais que aqui não puderam ser transcritos. Estas alterações, aliás, vão sempre indicadas nas notas ao pé das páginas.

Sempre o $x$ e o ch têm o mesmo valor - fricativa palatal surda; o ç é igual ao $c$ (antes de $-e,-i$ ) e ao $s$ fricativa dental surda; o $y$ de Figueira e $i$, às vezes $\hat{\imath}$, de Anchieta são o nosso $\ddot{u}$, com que está representada a vogal velar (gutural), não arredondada; o $u$ - (antes de vogal) de C. de Magalhães é igual ao $w$-de Tastevin; $g u$ - (antes de vogal) é igual a $g w$-; quanto ao $h$, v. nota 23 .

Também em virtude de deficiência tipográfica, empregou-se aqui o travessão (-) em lugar da flecha ou antilambda, para indicar que uma forma originou ou origina-se de outra. Assim, sempre que se tiverem duas formas separadas por um travessão, entender-se-á que a forma da esquerda provém da forma da direita. Ex.: porã - porá quer dizer que a forma porá provém ou originou-se da forma porã'; $m b-m$ quer dizer que o fonema $m$ provém do fonema $m b$, ou que o fonema $m b$ evoluiu para $m$. 
O til ( ) sobre $e, i, u$ foi substituído por um $n$, entre parênteses, após essas vogais: $e(n), i(n), u(n)$.

\section{官}

A parte deste estudo intitulada - "As Consoantes Finais do Proto-Tupí-Guaraní" - já foi publicada, sob a epigrafe - "Um Pouco de Tupinologia: Um aspecto da evolução fonética na família Tupí-Guaraní”, na Revista Filológica, Ano V, vol. VII, n. 29 (novembro de 1944), págs. 74-77. Aqui aparecem pequenas alterações, que se prendem somente à forma, não alterando em nenhum ponto o estudo.

\section{Referências}

Anchieta, Pe. Joseph de, 1933, Arte de gramática da língua mais usada na costa do Brasil, ed. da Bibl. Nacional do Rio de Janeiro, Rio.

Ayrosa, Plínio, 1939, Dos índices de relação determinativa de posse no Tupí-Guaraní, Boletim n 1 da Cadeira de Etnografia Brasileira e Língua Tupí-Guaraní, da Faculd. de Filos., Ciências e Letras da Univers. de S. Paulo, S. Paulo.

Bertolaso Stella, Jorge, 1929, As línguas indígenas da América, sep. da Rev. do Inst. Hit. de S. Paulo, v. XXVI (1928), S. Paulo.

Bertoni, Moisés S., 1940, Estructura, fundamentos gramaticales y clasificación de la lengua guaraní (Apunte póstumo), in Rev. de la Sociedad Científica del Paraguay, t. V, n 1 , Asunción.

Childe. A., 1940, Étude philologique sur les noms du "chien" de l'antiquité jusqu'à nos jours, in Arquivos do Museu Nacional, vol.XXXIX, Rio.

Couto de Magalhães, Gal., 1940, O selvagem. $4^{\mathrm{a}}$ ed., S. Paulo/Rio/Recife/P. Alegre.

Couto de Magalhães. Gal., 1940, Curso de língua tupí viva ou nheengatu, in O Selvagem, do mesmo autor, S. Paulo/Rio/Recife/P. Alegre.

Figueira, Pe. Luís, 1880, Arte de gramática da língua brasílica, ed. de Emilio Allain, Rio.

Froes de Abreu, Sílvio, 1931, Vocabulário Guajajara, in Na Terra das Palmeiras, do mesmo autor, Rio.

Ihering, Hermann von, 1907, A antropologia no estado de S. Paulo, in Rev. do Museu Paulista, t. VII, 8. Paulo.

Léry, Jean de, 1926, História de uma viagem à terra do brasil, trad. de Monteiro Lobato, Rio/S. Paulo.

Mansur Guérios, Rosário Farani, 1935, Novos rumos da tupinologia, sep. da Rev. do Círculo de Estudos Bandeirantes, t. 1, n 2, Curitiba.

Mansur Guérios, Rosário Farani, 1937, Pontos de gramática histórica portuguesa, S. Paulo.

Mansur Guérios, Rosário Farani, 1939, Pontos de método da fonética histórica, Curitiba. 
Mattoso Câmara Jr., Joaquim. 1942, Princípios de linguística geral, Rio.

Montoya, Pe. Antonio Ruiz de, 1876, Gramatica y diccionarios (arte, vocabulario y tesoro) de la lengua tupí ó guaraní, ed. do Visc. de Porto Seguro, Viena/Paris.

Ortiz Mayans, Antonio, 1941, Breve Diccionario guaraní-castellano - castellano-guaraní, Buenos Aires.

Sampaio, Teodoro, 1914, O tupí na geografia nacional, $2^{\mathrm{a}}$ ed., S. Paulo.

Snethlage, Emil Heinrich, 1932, Worte und texte der Tembé-indianer, aufgezeichnet von Cyriaco Baptista (tembe), in Rev. del Instit. de Etnologia de la Univers. Nacional de Tucumán, t. II, entrega $2^{\text {a }}$, Tucumán.

Steinen, Karl von den, 1942, O Brasil central, trad. de C. Baratz Canabrava, S. Paulo/ Rio/Recife/P. Alegre.

Sympson, Pedro Luís, 1925, Gramática da língua brasileira (brasílica, tupí ou Nheengatú), $2^{\text {a }}$ ed., Rio.

Tastevin, Pe. Constantino, 1923, Vocabulário tupí-português, in Rev. do Museu Paulista, t. XIII, S. Paulo.

Tenorio d'Albuquerque, Miguel, 1929, Apontamentos para a gramática avá-ñê, in Rev. do Museu Paulista, t. XVI, S. Paulo.

Trombetti, Alfredo, 1923, Elementi di glottologia, Bologna. 